\title{
ブドウ酒醇造工業におけるアルミニゥム およびその合金の利用について（第11報）
}

\author{
陽 極処 理 被 膜の赤ブドウ酒 \\ に対する防食効果についで
}

\section{森永 卓一 $* *$ 財㴖 鎮雄 $* * *$ 加賀美元男****}

On the utilization of aluminium and its alloys in the wine and brandy industry (11 th Report)

(UDC620 • 193 • $46: 661 \cdot 72: 669 \cdot 715$ )

On the anti-corrosive effect of the treated surface of aluminium alloy by anode oxidation process in red wine

MORINAGA Takuichi** ZAIMA Shigeo*** KAGAMI Motoo****

Following the previus report on the anti-corrosive property of protective film on the surface of aluminium in brandy and white wine, this report discusses on same property of the film, produced under anodizing process by use of a mixed acid (sulphalic acid and oxalic acid), in red wine, which attacks aluminium quite hard. Particularly, the anti-corrosive effect of the surface treatment in case of a part (1.78\%) of the surface being remained untreated was examined under the corrosion test in red wine.

It is appreciated that this study has owed its expenses to the Grant-in aid of the Scholarship of the Institute of Light Metal Foundation.

(Received May 30, 1959)

\section{1. 緒言}

硫酸・鉴酸の混酸処理による陽極酸化被膜が不十分な がらもブランデーおよび白ブドウ酒に対して比較的良好 な耐食効果を示したので, 1)2）さらにアルミニウム材料 に対して激しい腐食作用を示す赤ブドウ酒に対する耐食 効果を求めてみた。

\section{2. 実験 条件}

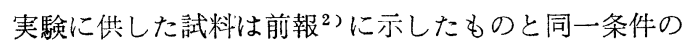
ものである。すなわち， $50 \times 10 \times 1 \mathrm{~mm}$ の $1 \mathrm{~S}$ 冷間圧延 材に3〜 $15 \mu$ の範囲で 5 種類の膜厚の被膜好理したもの (以下完全処理試料と称する)と, 処理が不完全の場合の
一部生地露出の影響をみるため同寸法の $1 \mathrm{~S}$ および $2 \mathrm{~S}$ の板状試験片の両端を未好理のままにして（未好理表面 積は全表面積の約1.78\%に相当する） 6 〜 $14 \mu$ にそれぞ れ 3 種類の被膜処理した（以下不完全処理試料と称す る) Table 1 に示す試料区分に従つた。これらの試料を Table 2 に示す山梨県産ブドウ品種「Black Queen」 を原料として锼造した赤ブドウ酒（1956年製）中に浸清 して, 試料の被膜外観の変化・重量変化などを調べ，他 方浸清日数の経過による赤ブドウ酒の変化を測定して, 被膜の赤ブドウ酒に対する酎食効果を検討した。

以下に結果を示すが，その際採用した各種分析方法は アルミニウム材粨の赤ブドウ酒に対する耐食性を検討し

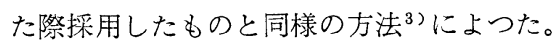

* 本報告は一部日本機械学会北関東地方講演会 (34-6-12) において講演

** 東京工業大学教授 (金属工学教室) 工博 Prof. Tokyo Institute of Technology, Dr. Eng.

***. 山梨大学工学部助教授 (機械工学科) Assist. Prof. Faculty of Engineering, Yamanashi Univ. ****山梨大学工学部助教授 (醱睹研究所) Assist. Prof. Research Institute of Fermentation, Yamanashi University. 
Table 1 The surface treatment on the specimen for corrosion test by the anode oxidation process.

\begin{tabular}{|c|c|c|c|}
\hline 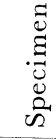 & 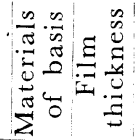 & Treatment & Used acid \\
\hline
\end{tabular}

No. $1 \quad 2 \mathrm{~S} \quad 3 \mu$ Whole surface

Mixed acid $\left(\begin{array}{l}\text { Sarpharic acid } \\ \text { +oxalic acid }\end{array}\right)$

No. 2 2 $\mathrm{S} 6$ Whole surface

\begin{tabular}{ll|l|l|l} 
No. & 3 & $2 \mathrm{~S}$ & 9 & Whole surface
\end{tabular}

Mixed acid

Mixed acid

No. 4 2 $\mathrm{S}: 12$ Whole surface

No. 5 2 $\mathrm{S} 15$. Whole surface

No. 6 1 $1 \mathrm{~S} \quad 6 \quad \begin{gathered}\text { A part(1.78\% surface) } \\ \text { untreated }\end{gathered}$

Mixed acid

Mixed acid

Mixed acid

No. 7 1 S 9 A part(1.78\% surface) untreated

No. 8 1 S 14 A part(1.78\% surface) untreated

No. $92 \mathrm{~S} 6$ A part(1.78\% surface) untreated

Mixed acid

Mixed acid

Mixed acid

No. 10 2S 9 A part(1.78\% surface)

No.11 2S $14 \quad \begin{aligned} & \text { A part(1.78\% surface) } \\ & \text { untreated }\end{aligned}$

Mixed acid

Mixed acid

Table 2 The analysis of the raw red wine.

Al- Total Ex- Tan- Main mineral contents. cohol acid tract $\mathrm{nin} \mathrm{pH} \quad(\mathrm{mg} / \mathrm{l})$

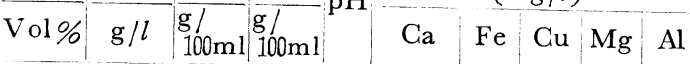

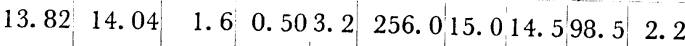
\begin{tabular}{c|c}
$\mathrm{Re}-$ & Raw materials of wine $=$ Black queen. (1956)
\end{tabular}

\section{3. 処理被膜における変化}

浸㨊日数の経過にしたがつて被膜はいうれも変化を受 け, その実態は Table 3に示すとおりである。完全処理 試料でも不完全処理試料でも約10日でピツトが発生した が, 膜厚の厚いもの程その程度が少なかつた。しかし約 60 日程度になればいづれもピットの発生はかなり激しくな り,わずかなピンホール・処理不均一部分などと思われ る処より腐食の進行がはじまるようで, また生地材料に よるちがいはわずかに $1 \mathrm{~S}$ の方が優れているようではあ つたが，顕著ではなかつた。不完全処理試料では生地の 簬出部分での腐食がとくに激しかつたのは前報の結果 ${ }^{2}$ と同様であつた。以上に对応して腐食の進行による試料 の重量減少は完全処理試料で Fig. 1，不完全処理試料で は Fig. 2 のようになつた。完全処理試料では膜厚の増 加に従つて重量減少の程度が急激に少なくなつており, 不完全処理試料では $1 \mathrm{~S}$ が $2 \mathrm{~S}$ に比べやや減少の程度が 少ないようではあるが，膜厚に関係なくいづれも重量の
Table 3 The change of the treated surface of specimen in red wine.

\begin{tabular}{|c|c|c|c|c|c|c|c|}
\hline Days 0 & 0 & 5 & 10 & 20 & 30 & 60 & Remark \\
\hline No. 1 & & - & + & + & \pm+ & ++ & \\
\hline No. 2 & & - & + & + & \pm+ & \pm+ & \\
\hline No. $3-$ & & - & + & + & + & + & \\
\hline No. 4 & & - & \pm & \pm & + & + & \\
\hline No. 5 & & - & \pm & + & + & + & \\
\hline No. $6-$ & & - & \pm & + & + & \pm+ & $\begin{array}{l}\text { Untreated surface } \\
\text { corrod. }\end{array}$ \\
\hline No. 7 & & - & - & \pm & + & \pm+ & $\begin{array}{l}\text { Untreated surfacd } \\
\text { corrod. }\end{array}$ \\
\hline No. $8-$ & & - & - & - & \pm & + & $\begin{array}{l}\text { Untreated surface } \\
\text { corrod. }\end{array}$ \\
\hline No. $9-$ & & - & \pm & + & \pm+ & ++ & $\begin{array}{l}\text { Untreated shrface } \\
\text { corrod. }\end{array}$ \\
\hline No. 10 & - & - & \pm & \pm & \pm & + & $\begin{array}{l}\text { Untreated surface } \\
\text { corrod. }\end{array}$ \\
\hline No. $11-$ & & - & - & \pm & \pm & + & $\begin{array}{l}\text { Untreated surface } \\
\text { corrod. }\end{array}$ \\
\hline
\end{tabular}

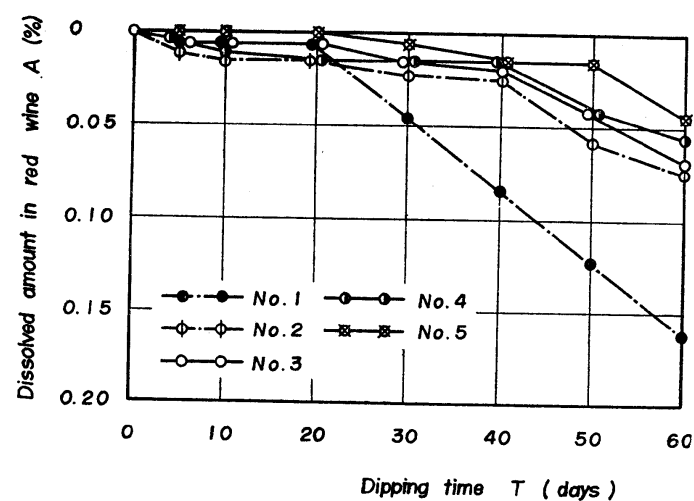

Fig. 1 The relation between the dipping time and the change of weight in the case of the whole surface treated specimen.

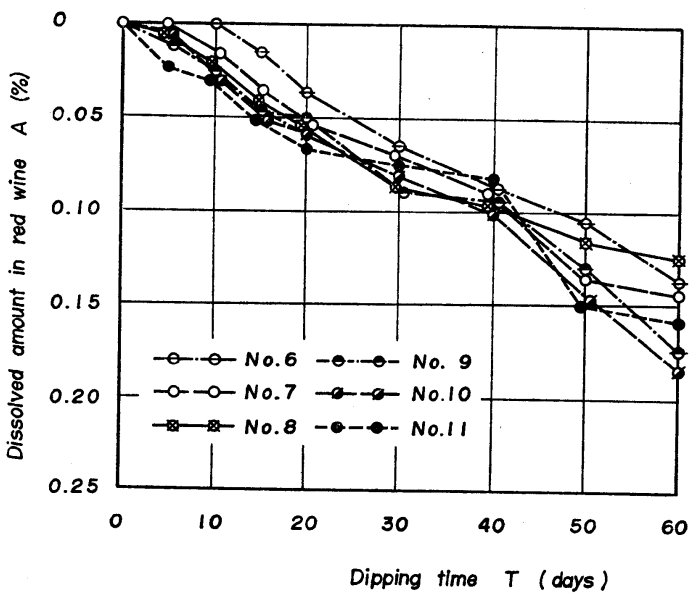

Fig. 2 The relation between the dipping time and the change of weight in the case of the specimen retaind $1.78 \%$ untreated surface. 
Table 4 The fading of the wine colour in red wine.

\begin{tabular}{|c|c|c|c|c|c|c|}
\hline Days & 0 & 10 & 20 & 40 & 60 & Remark \\
\hline No. 1 & - & - & - & - & + & Dark red purple \\
\hline No. 2 & - & - & - & \pm & \pm & Dark red purple \\
\hline No. 3 & - & - & - & - & - & Dark brown purple \\
\hline No. 4 & - & - & - & - & - & Dark brown purple \\
\hline No. 5 & - & - & - & - & - & Dark brown purple \\
\hline No. 6 & - & - & \pm & \pm & \pm & Dark red purple \\
\hline No. 7 & - & - & - & \pm & \pm & Dark red purple \\
\hline No. 8 & - & - & - & \pm & \pm & Dark red purple \\
\hline No. 9 & - & - & \pm & \pm & + & Dark red purple \\
\hline No. 10 & - & - & \pm & \pm & + & Dark red purple \\
\hline No. 11 & - & - & - & \pm & \pm & Dark brown purple \\
\hline
\end{tabular}

- Immutable state, +Fading state.

Table 5 The change of the wine compositions in red wine by dipping specimen.

\begin{tabular}{c|c|c|c|c|c|c|c}
\hline & \multicolumn{2}{|c|}{$\begin{array}{c}\text { Alcohol } \\
\mathrm{g} / 100 \mathrm{ml}\end{array}$} & \multicolumn{2}{|c|}{ Extract } & \multicolumn{2}{|c}{ Tannin } \\
\hline Days & 0 & 60 & 0 & 60 & 0 & 60 \\
\hline No. 1 & 13.82 & 13.73 & 1.6 & 1.5 & 0.50 & 0.45 \\
No. 2 & 13.82 & 13.73 & 1.6 & 1.2 & 0.50 & 0.47 \\
No. 3 & 13.82 & 13.82 & 1.6 & 1.3 & 0.50 & 0.47 \\
No. 4 & 13.82 & 13.82 & 1.6 & 1.3 & 0.50 & 0.45 \\
No. 5 & 13.82 & 13.73 & 1.6 & 1.3 & 0.50 & 0.48 \\
No. 6 & 13.82 & 13.82 & 1.6 & 1.4 & 0.50 & 0.44 \\
No. 7 & 13.82 & 13.82 & 1.6 & 1.4 & 0.50 & 0.45 \\
No. 8 & 13.82 & 13.80 & 1.6 & 1.4 & 0.50 & 0.44 \\
No. 9 & 13.82 & 13.80 & 1.6 & 1.5 & 0.50 & 0.45 \\
No. 10 & 13.82 & 13.80 & 1.6 & 1.4 & 0.50 & 0.44 \\
No. 11 & 13.82 & 13.80 & 1.6 & 1.6 & 0.50 & 0.44 \\
\hline
\end{tabular}

Table 6 The change of the main mineral contents in red wine.

\begin{tabular}{c|c|c|c|c|c|c}
\hline & \multicolumn{2}{|c|}{$\mathrm{Fe}$} & \multicolumn{2}{c|}{$\mathrm{Cu}$} & \multicolumn{2}{|c}{$\mathrm{Al}$} \\
\hline & \multicolumn{2}{|c|}{$\mathrm{mg} / \mathrm{l}$} & $\mathrm{mg} / \mathrm{l}$ & \multicolumn{2}{c}{$\mathrm{mg} / \mathrm{l}$} \\
\hline Days & 0 & 60 & 0 & 60 & 0 & 60 \\
\hline No. 1 & 15.0 & 15.2 & 14.5 & 14.3 & 2.2 & 2.2 \\
No. 2 & 15.0 & 15.3 & 14.5 & 14.5 & 2.2 & 2.0 \\
No. 3 & 15.0 & 15.0 & 14.5 & 14.3 & 2.2 & 2.0 \\
No. 4 & 15.0 & 15.0 & 14.5 & 14.3 & 2.2 & 2.0 \\
No. 5 & 15.0 & 15.2 & 14.5 & 14.7 & 2.2 & 2.2 \\
No. 6 & 15.0 & 14.8 & 14.5 & 14.3 & 2.2 & 2.4 \\
No. 7 & 15.0 & 15.0 & 14.5 & 14.3 & 2.2 & 2.2 \\
No. 8 & 15.0 & 14.8 & 14.5 & 14.5 & 2.2 & 2.3 \\
No. 9 & 15.0 & 15.1 & 14.5 & 14.3 & 2.2 & 2.5 \\
No. 10 & 15.0 & 14.8 & 14.5 & 14.5 & 2.2 & 2.2 \\
No. 11 & 15.0 & 14.8 & 14.5 & 14.5 & 2.2 & 2.4 \\
\hline
\end{tabular}

減少が甚だしかつた。

\section{4. 赤ブドウ酒の変化}

白ブドウ酒では浸清に伴い浮遊浓測物を生じて一旦白 濁するのが普通であつたが，4２）赤ブドウ酒では約100日 程度では沈澱物の析出は明膫には認められなかつた。し かし浸潰日数についてその特有な色調に Table 4 のよう に哴色が認められるものがあつた。完全処理試料の中で は膜厚の薄いものと不完全処理試料, すなわち試料の重 量減少の比較的多いものでは, いわゆる紫根（瞕い茶紫 Dark brown purple）調のものが斏色変化してダリアパ ープル (こい赤紫 Deep red purple) 調の鮮やかな色 調になつた。5) 従つて色紊と密接な関係にあるタンニン 量は Table 5 のように, いづれも減少の傾向にあるこ とは不思議なことではないように思われる。また，工キ ス分もアルコール分も日数の経過とともに Table 5 のよ うに多少隇少の傾向にあつた。

試料の重量滅少に伴いその主要金属成分の行方を確認 するため，60日後の赤ブドウ酒中の金属成分を求めれば

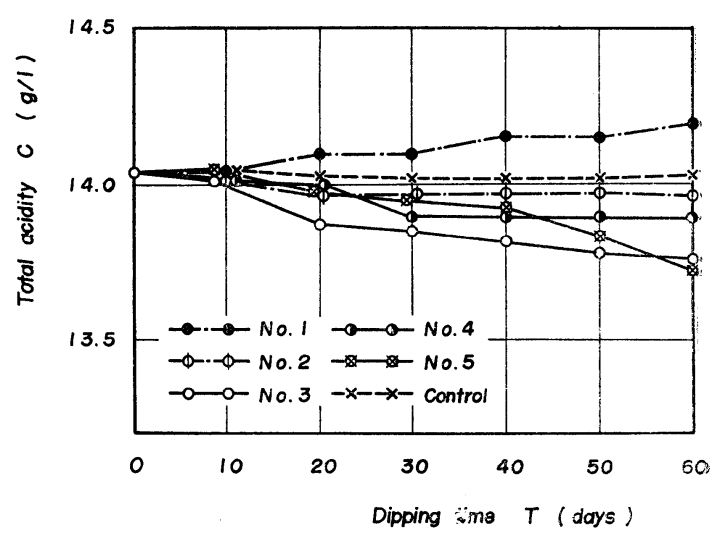

Fig. 3 The change of the total acidity by dipping the whole surface treated specimen.

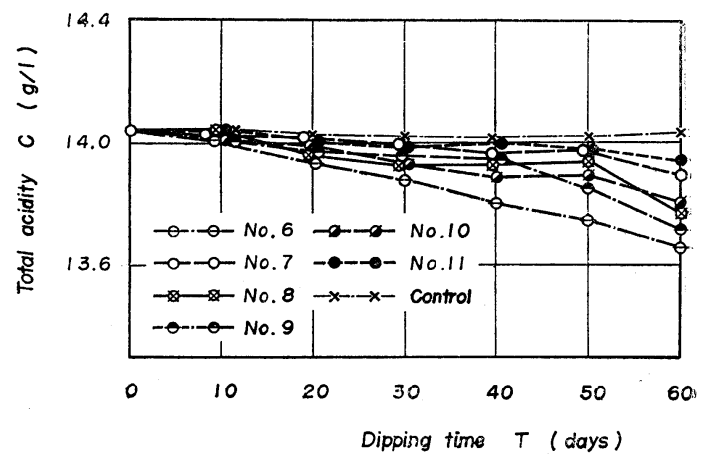

Fig. 4 The change of the total acidity by dipping the specimen retained $1.78 \%$ untreated surface. 


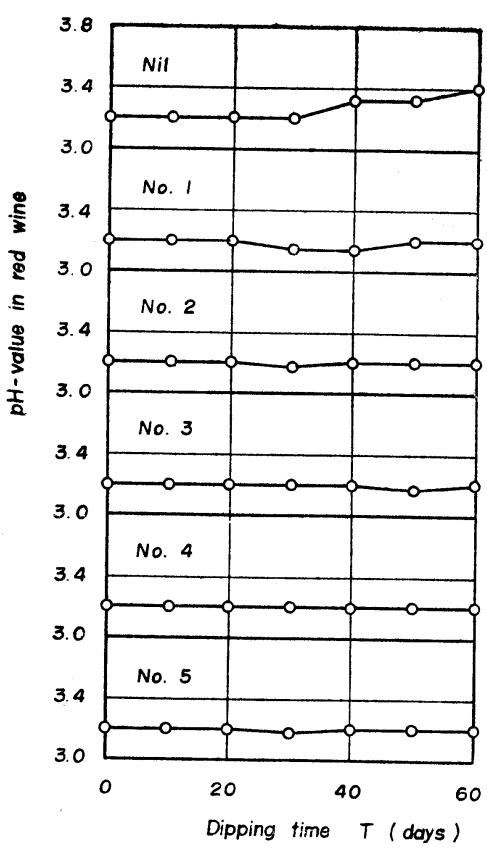

Fig. 5 The change of the $\mathrm{pH}$-value in red wine by dipping the whole surface treated specimen.

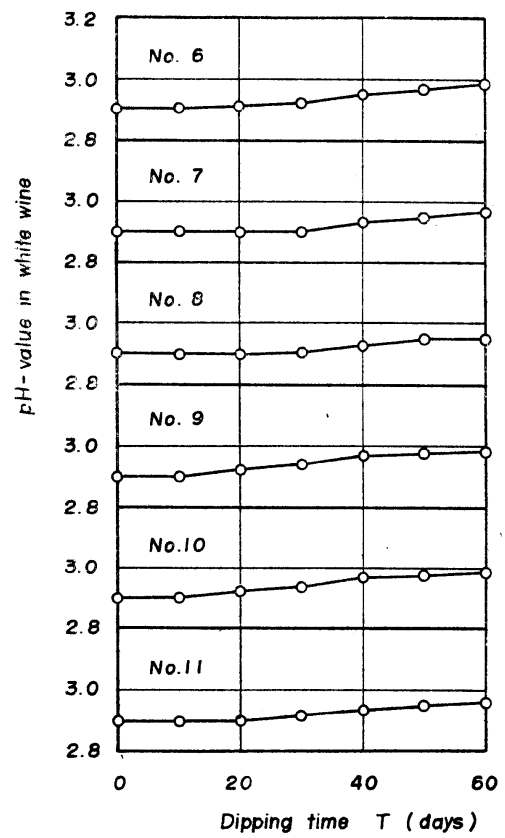

Fig. 6 The change of the $\mathrm{pH}$-value in red wine by dipping the specimen retained $1.78 \%$ untreated surface.

Table 6 のようになり， $\mathrm{Fe}, \mathrm{Cu}$ いうれも実験䛊差範囲 とみられる程度の変動であり，またとくに試料の主成分 であるアルミニウムについても明膫な変化はみられない が，生地の露出した不完全処理の場合幾分増加の傾向に
Table 7 The organoleptic testing of red wine in index ewpression.

\begin{tabular}{|c|c|c|c|c|c|c|}
\hline Spcimen & Days & Flavor & Palate & $\begin{array}{l}\text { har- } \\
\text { ctor }\end{array}$ & Rem & lark \\
\hline No. 1 & 60 & 2 & 2 & 2 & Faded & state \\
\hline No. 2 & 60 & 2 & 2 & 2 & Faded & state \\
\hline No. 3 & 60 & 2 & 2 & 2 & & \\
\hline No. 4 & 60 & 2 & 2 & 2 & & \\
\hline No. 5 & 60 & 2 & 2 & 2 & & \\
\hline No. 6 & 60 & 4 & 4 & 4 & Faded & state \\
\hline No. 7 & 60 & 4 & 3 & 4 & Faded & state \\
\hline No. 8 & 60 & 2 & 2 & 2 & Faded & state \\
\hline No. 9 & 60 & 3 & 4 & 4 & Faded & state \\
\hline No. 10 & 60 & 5 & 5 & 5 & Faded & state \\
\hline No. 11 & 60 & 3 & 3 & 4 & Faded & state \\
\hline Control & 60 & 1 & 1 & 1 & & \\
\hline
\end{tabular}

あるとみれないでもない。

総酸量の変化を求めれば完全処理試料で Fig. 3，不完 全処理ではFig.4のようになる。1〜2の例外にもあるが， 大体において極くわずかであるが次第に減少の傾向にあ るようである。今までの結果では白ブドウ酒の場合でも 実験範䎴の日数はほとんど変化しないか極くわづかの減 少程度であつたが，前回の年間予備実験4)ではわずかで はあるが明らかに減少の傾向をとつた。しかも総酸と密 接な関係をもつと思われるpHの変化は Fig. 5(完全処理 試料), Fig. 6(不完全処理試料)にみるように，ほとんど 変化しないが多少増加の傾向にあり総酸の変化と相反す る変化をとる。このことは今までの結果 ${ }^{1 \sim 4)}$ と一致して おり, かつ $\mathrm{pH}$ の上昇とともに赤ブドウ酒の香・味, 従 つてその品格が劣化するという従来からの著者の見解と 矛盾しない。すなわち，「きき酒」試験の結果はTable 7 のようになり, いうれれ場合も香・味従つてその品格 は原酒 (control) にくらべてその指数が増加している。 とくに不完全処理試料では完全処理試料に比べてさらに 指数が大きく, 従つて劣化の度合が大きくかつ露出生地 が $2 \mathrm{~S}$ の方が $1 \mathrm{~S}$ の場合より劣化が甚だしく, 膜厚の薄 い方が結果がよくない。

\section{5. 総括}

以上, 硫酸・苳酸の混酸処理による Table 1 に示す ような区分に従つた陽極酸化処理被膜について, 赤ブド ウ酒に対する防食効果およびその際の赤ブドウ酒の変化 について検討した結果，

(1) 完全処理試料でも実験範囲では膜厚にかかわらず 約10〜20日でピットの発生がみられ，実用化に対しては さらに検討の必要があつた。

（26頁に続く） 
Table 9 The organoleptic testing of white wine in index expression.

\begin{tabular}{c|c|r|r|r|r}
\hline Specimen & Days & Flavor & Palate & Charactor & Remark \\
\hline No. 1 & 60 & 1 & 2 & 2 & \\
No. 2 & 60 & 2 & 2 & 2 & \\
No. 3 & 60 & 1 & 1 & 1 & \\
No. 4 & 60 & 1 & 1 & 1 & \\
No. 5 & 60 & 1 & 1 & 1 & \\
No. 6 & 60 & 3 & 3 & 3 & Turbid state \\
No. 7 & 60 & 3 & 3 & 3 & Turbid state \\
No. 8 & 60 & 2 & 2 & 2 & Turbid state \\
No. 9 & 60 & 5 & 4 & 5 & Turbid state \\
No. 10 & 60 & 2 & 3 & 3 & Turbid state \\
No. 11 & 60 & 3 & 3 & 3 & Turbid state \\
Control & 60 & 1 & 1 & 1 & \\
\hline
\end{tabular}

かわらず $\mathrm{pH}$ に明膫な増加が認められる場合が多く, し かもこの際ブドウ酒類の香・味従つてその品格も低下し たが ${ }^{1 \sim 4)}$ ，今回も「きき酒」試験の結果は Table 9 の ようになつた。すなわち， $\mathrm{pH}$ が上昇したものはいつれ も香・味が劣化し，かつ不完全処理試料ではいつれれそ の傾向があり, 露出生地は $2 \mathrm{~S}$ の方が結果がよくなかつ た。また完全処理・不完全処理試料を問わず膜厚のうす いもの程劣化が目立つようであつた。

\section{6. 総 括}

以上苳酸, 硫酸の混酸処理による Table 2 に示すよ
うな陽極酸化被膜の白ブドウ酒に対する耐食効果および 白ブドウ酒に与える影響について検討した結果，

(1) 完全処理した結果は膜厚 $9 \mu$ 以上ではピットの発 生が少なく，白ブドウ酒に与える悪影響も少なく実用性 の見込みがあつた。(但し処理不均一と思われる隅角の 部位よりの腐食が幾分認められたので，さらに処理に細 心の注意と，例えば水硝子などによる被膜処理のような ことを考虑する必要がある。)

(2) 生地材料の露出した不完全処理の場合は露出部分 よりの腐食が激しく, 白ブドウ酒は香・味従つて品格の 低下が甚だしく実用性はなかつた。また，その際は生地

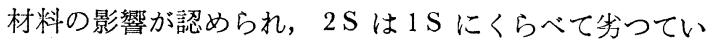
た。

本研究は一部財団法人軽金属奖学会の研究資金によつ たことを附記し，ここに同会の御好意に深甚なる感謝の 意を表する。また実験に御協力いただいた北陸軽金属 (株)池野尚志氏, 昭和アルミニウム(株)潮田豊治氏に厚 く御礼申上ぐる次第である。

\section{参 考 文 献}

1）森永, 財満, 加賀美 : 軽金属 Vol. 9, No. 35 (1959), p. 55.

2）森永，財満，加賀美：軽金属 Vol. 9， No. 36 (1959), p. 5.

3）森永, 財満, 加賀美 : 軽金属 Vol. 8, No. 30 (1958), p. 26.

4) 森永, 財満, 加賀美 : 軽金属 Vol. 8, No. 31 (1958), p. 40.

30 頁より続く

（2）一部生地材料が露出した場合には生地材料による 耐食性の差がみられた。

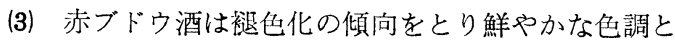
なるが，香・味従つてブドウ酒の品格の低下がみられ， とくに不完全処理試料で甚だしかつた。

本報告は一部財団法人軽金属奖学会の研究資金によつ たことを附記し：ここに同会の御好意に深靦なる感謝の 意を表する。また実験に御協力いただいた北陸軽 金属 (株)池野尚志氏，昭和アルミニウム(株)潮田豊治氏に厚 く御礼申上ぐる次第である。

\section{参 考 文 献}

1）森永，财満，加賀美：軽金属 Vol. 9, No. 36(1959) p. 5.

2）森永, 財満, 加賀美 : 軽金属 Vol. 9, No. 37(1959) p. 22 .

3）森永, 財満, 加賀美：軽金属 Vol.9, No. 34(1956) p. 68.

4）森永, 財満, 加賀美：軽金属 Vol. 9, No. 35(1959) p. 55.

5）日本色彩研：新色名帖（昭31）によつた。

\section{軽金属研究会入会手続}

軽金属研究会は軽金属（アルミニウム，マグネシウム，チタニウム等）事業に閣歴又は関係ある個人は誰 でも入会できます。会員ば軽金属”に投稿し無償頒布を受け各種会合催し物にも出席出来ます。

御希望の方は，(1)氏名，(2)生年月日，(3)自宅，(4)勤務先の住所名称地位.(5)主な学歴（最終卒業年月日) 学位称号，(6)主な学歴を記入した入会申込書（様式適宜）に会費 600 円を添えて御送付下さい。会費は小為 替又は振替口座（東京118744番）軽金属協会を御利用下さい。 